\title{
FAREWELL
}

$\mathrm{T}$ his will be the last journal to be published in 1999 and this will be my last journal as the editor: What is all this fuss about the 'New Millenium'? I have heard this comment made by a number of people, and decided to give it some thought. Most people alive today were not yet born at the change of the last century and those who are must be relatively very few. Surely it is special to experience this event. In the words of Winston Churchill 'when a man cannot distinguish a great from a small event, he is of no use'. Is this not a time for reflection of the past and hopes and wishes for the future? The great statesman also said, beware of the tyrany of the Dark Goddess of continual accomplishment'. We have always referred to this journal as 'the mouth piece of the profession". It must follow that the editor must be involved, committed and sensitive to the status of the profession and must have a finger on the pulse and interpret the heartbeat. This sensitivity should result in interpreting the signs of the need for new input. I believe that the old guard should be aware of when to step down and make way for new and fresh ideas, even though this may well be at a time when they consider themselves to be at a peak.

The first South African Journal of Physiotherapy was published in June
1929 and the first editor was Miss Drubin of Cape Town. The journal was initially called the Journal of Massage and Medical Gymnastics and the name was changed in 1932 to the South African Journal of Physiotherapy. To the best of my knowledge the journal has since then been published quarterly. One of the attributes of a true profession is its publication. This journal is peerreviewed which enhances its value and the next step must be to have it reflected in Index Medicus. I wonder how many of you have noticed that the quality of the paper in the last journal was improved and that the number of pages has increased. There have been publications from or pending, from all the teaching units and submissions from a variety of people working in different communities. There are already manuscripts in the bank for the next journal, which is a credit to the readers of this journal, and 1 hope that more and more people will want to publish in our journal.

I want to thank you all for giving me the opportunity to edit this journal and for the support and encouragement that I have received. I leave with only one regret and that is that I did not succeed in a free and flowing communication between readers through 'Letters to the Editor'.

Having sketched the picture of what I consider the attributes of the editor of a

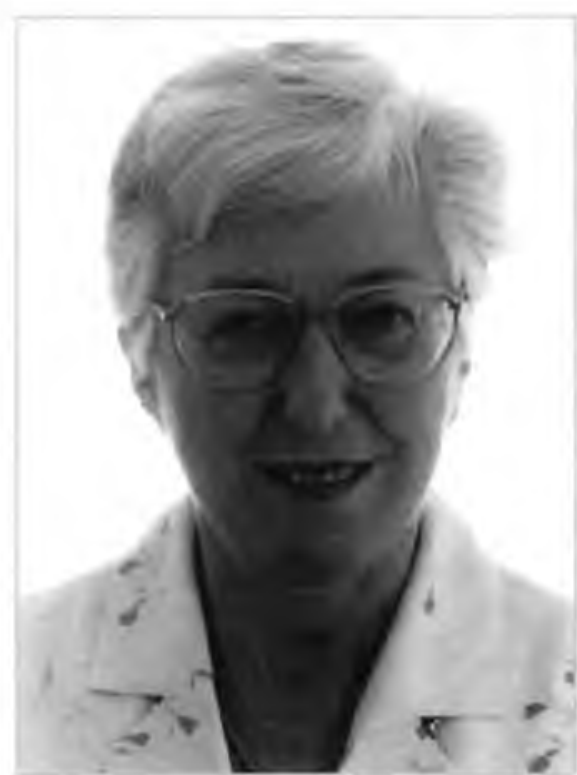

journal to be, I confidently hand over the reins to Professor Sielie Eales. I wish her success and good luck. It is said 'that if you want something done, give it to the busiest person'.

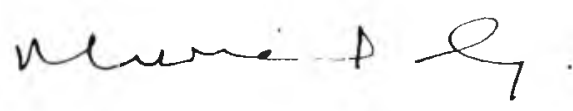

MURIEL GOODMAN EDITOR

\section{REVIEWERS THANK YOU}

\section{Many thanks and our sincere appreciation to the following people:}
D. Amosun
R. Bernstein
D. Cohen
P. De Witt
S. De Charmoy
K. Ermann
L. Fearnhead
G. Giraud
B. Gounden
L. Hale
L. Hunter
S. Irwin-Curruthers

H. Isaacs

A. Kastanos

A. Marais

B. Price

M. Riley

A. Stewart 